\title{
Description of Bacteroides loescheii sp. nov. and Emendation of the Descriptions of Bacteroides melaninogenicus (Oliver and Wherry) Roy and Kelly 1939 and Bacteroides denticola Shah and Collins 1981
}

\author{
LILLIAN V. HOLDEMAN AND JOHN L. JOHNSON \\ Department of Anaerobic Microbiology, College of Agriculture and Life Sciences, Virginia Polytechnic \\ Institute and State University, Blacksburg, Virginia 24061
}

\begin{abstract}
Bacteroides loescheii, a new species from periodontal pockets and superficially cleaned tooth surfaces coronal to gingival margins and from various types of human infections, is described. Strains of $B$. loescheii are obligately anaerobic, gram-negative, usually pigmenting, nonmotile, nonsporeforming rods that do not grow well in $10 \%$ bile and that ferment carbohydrates. These strains previously were identified as Bacteroides melaninogenicus or Bacteroides oralis, but they have no deoxyribonucleic acid homology with the type strain of either of these two species. The type strain of $B$. loescheii is ATCC 15930. The descriptions of $B$. melaninogenicus and Bacteroides denticola are emended.
\end{abstract}

In 1921 Oliver and Wherry (28) described as "Bacterium melaninogenicum" strains of obligately anaerobic, nonmotile, gram-negative, saccharoclastic rods that produce black growth on agar slants containing human blood. Oliver and Wherry noted that "growth of the bacteria on infusion agar is greatly facilitated by the presence of hemoglobin, and pigment production is absolutely dependent on it." The strains studied by Oliver and Wherry were isolated from throats, tonsils, an infected surgical wound of the abdomen, urine, and the "feces of a case of chronic dysentery superimposed on an original amebic (sic) infection." These authors also stated that similar pigment-producing colonies had been found by other investigators in cultures from carious teeth.

Despite its requirement of an anaerobic environment for growth, in the third edition of Bergey's Manual of Determinative Bacteriology the species was classified in the genus Hemophilus (sic), which was described as containing aerobic species (2). In the fifth edition of Bergey's Manual, Roy and Kelly placed the species in the genus Bacteroides (31). Schwabacher et al. (34) reported that the black pigment was not melanin, as originally postulated by Oliver and Wherry, suggested that the specific epithet of the species should be changed from "melaninogenicus" to "nigrescens" and, in keeping with the nomenclature used in Topley and Wilson's Principles of Bacteriology and Immunity (44), proposed the new combination "Fusiformis nigrescens." Other synonyms are "Ristella melaninogenica" (Oliver and Wherry) Prévot 1938 (29) and "Fusiformis melaninogenicus" (44).

Until 1976, anaerobic gram-negative bacteria that produced brown or black colonies on blood agar were identified as $\boldsymbol{B}$. melaninogenicus (or one of the synonyms), despite the fact that phenotypic diversity had been reported for $\mathbf{4 5}$ years. In 1928 Burdon (4) described strains of "B. melaninogenicum" that were not saccharoclastic, were proteolytic, and produced indole. These strains resembled those studied by Oliver and Wherry only in that they formed colonies with a black pigment on blood agar. Through the seventh edition of Bergey's Manual and through the 1957 edition of the Manuel de Classification et de Détermination des Bactéries Anaérobies (30), descriptions of $B$. melaninogenicus were composites of the characteristics reported by Oliver and Wherry and those reported by Burdon. Based on their own observations and the reports of Sawyer et al. (33), Holdeman and Moore (13) recognized the following three subspecies: B. melaninogenicus subsp. melaninogenicus, B. melaninogenicus subsp. intermedius, and $B$. melaninogenicus subsp. asaccharolyticus. In a report of the ICSB Taxonomic Subcommittee on Gram-Negative Anaerobic Rods, Finegold and Barnes proposed reclassification of $B$. melaninogenicus subsp. asaccharolyticus as Bacteroides asaccharolyticus (7). Bacteroides gingivalis and Bacteroides macacae, also anaerobic gram-negative rods that produce 
colonies with black pigment, have been recognized as distinct from both $B$. asaccharolyticus and $B$. melaninogenicus (5).

Because there was considerable diversity among the strains classified as $B$. melaninogenicus, we initiated a study of deoxyribonucleic acid (DNA) homology among saccharolytic Bacteroides strains that form black pigment on blood agar medium. In 1980 one of us (J.L.J.) reported that there were three distinct homology groups, represented by the type strain and by strains VPI 10043 and VPI 12530, among 19 strains with the characteristics of $B$. melaninogenicus subsp. melaninogenicus (16). Phenotypic characteristics useful in differentiating among these homology groups also were described (16). The names " $B$. socranskii" and $B$. loescheii were proposed for the homology groups represented by VPI 10043 and VPI 12530 (L. V. Holdeman, J. L. Johnson, and W. E. C. Moore, J. Dent. Res. 60[Sp. Issue A]:414, abstr. no. 415, 1981). Later in 1981 Shah and Collins published the description of $B$. denticola (36) based on the study of NCDO 2352 (strain 1210) and strain 1221 , presumably from E. Barnes. DNA from strain 1221 has $100 \%$ homology with DNA from NCDO 2352, the type strain of $B$. denticola (36). Strain 1221, which we received from E. Barnes, has $85 \%$ homology with strain VPI 10043, which indicates that the homology group for which we had proposed the name " $B$. socranskii" is $B$. denticola. The name $B$. denticola has priority (38).

The results of studies of 59 strains that have characteristics originally described for $B$. melaninogenicus (28) are presented in this paper.

\section{MATERIALS AND METHODS}

Strains. The sources of the strains used in the DNA homology studies are given in Tables 1 through 3 . In addition, homology was tested with DNAs from VPI D27B-24 (the parent strain of ATCC 33269, the type strain of Bacteroides oralis, isolated from the gingival crevice of a person with severe periodontitis) and from reference strains for the three homology groups within B. melaninogenicus subsp. intermedius (Holdeman et al., J. Dent. Res. 60[Sp. Issue A]:414, abstr. 415, 1981). These included VPI 4197, the parent strain of ATCC 25611 (B. melaninogenicus subsp. intermedius); VPI 8944 (NCTC 9336), the parent strain of ATCC 33563; and VPI 9343, the parent strain of ATCC 33547 (Lambe strain 58-71A, isolated from a cervical swab [20]).

Methods of characterization. The phenotypic reactions of the strains were studied with the prereduced media and methods described previously $(11,32)$. For characterization of some strains, $10 \%$ (vol/vol) sterile rabbit serum was added to differential media to obtain maximum growth. In such cases, the $\mathrm{pH}$ values of cultures in media containing maltose, glycogen, and starch without added serum also were tested to verify fermentation of these substrates in the absence of serum amylase. To determine the effects of vitamin $\mathrm{K}$ and hemin on the growth of the organisms, peptoneyeast extract-glucose medium without vitamin $\mathrm{K}$ and hemin was prepared by using glassware and a dispensing apparatus that were free of vitamin $\mathrm{K}$ and hemin. Cultures were transferred sequentially for five transfers (or until no growth occurred) in the peptone-yeast extract-glucose medium without vitamin $\mathrm{K}$ and hemin and in the same medium to which vitamin $K_{1}$ and hemin were added either singly or together to give final concentrations of $1 \mu \mathrm{g} / \mathrm{ml}$ and $0.5 \mathrm{mg} / \mathrm{ml}$, respectively. The susceptibilities of the organisms to chloramphenicol $(12 \mu \mathrm{g} / \mathrm{ml})$, clindamycin $(1.6 \mu \mathrm{g} / \mathrm{ml})$, penicillin $\mathrm{G}(2$ $\mathrm{U} / \mathrm{ml})$, and tetracycline $(6 \mu \mathrm{g} / \mathrm{ml})$ were tested by using the broth disk method of Wilkins and Thiel (42). Polyacrylamide gel electrophoretic (PAGE) patterns of soluble cellular proteins were determined as described by Moore et al. (26).

DNA isolation. The organisms were grown in a medium that was prepared as described previously (6); this medium contained mineral salts, $1 \%$ pepticase, $0.5 \%$ yeast extract, $1 \%$ dehydrated brain heart infusion broth (Difco Laboratories, Detroit, Mich.), 1\% glucose, $0.03 \%$ cysteine, $0.03 \%$ sodium formaldehyde sulfoxalate, $0.01 \%$ heme, and $0.05 \mathrm{M}$ potassium phosphate buffer ( $\mathrm{pH} 7.0)$. At the time of inoculation, $10 \mathrm{ml}$ of $10 \%$ sterile $\mathrm{NaHCO}_{3}$ was added to each 1 liter of medium. Flasks containing 1 or 2.5 liters of medium were inoculated with 10 to $20 \mathrm{ml}$ of an overnight culture grown in chopped meat carbohydrate medium (11) and then incubated for 18 to $24 \mathrm{~h}$ at $37^{\circ} \mathrm{C}$. The harvested cells were suspended in a $0.15 \mathrm{M} \mathrm{NaCl}-0.01$ $\mathrm{M}$ ethylenediaminetetraacetic acid salt solution $(\mathrm{pH}$ 8.0). The cells were lysed by adding sodium dodecyl sulfate to a final concentration of $1 \%$. After a preliminary extraction with chromatography-grade phenol, high-molecular-weight DNA (for nick-translation labeling) was isolated by the method of Marmur (23). Other DNA preparations were isolated by a hydroxyapatite procedure (17).

Guanine-plus-cytosine content of DNA. Thermal melting points were used to determine the guanineplus-cytosine contents of the DNA preparations (17, 24).

Preparation of labeled DNA. Labeled DNA was prepared in vitro either by nick translation (17) or by iodination. Fragmented denatured DNA was labeled with ${ }^{125}$ I by using a variation of the thallium chloride method of Tereba and McCarthy (39). The reaction mixture containing $25 \mu \mathrm{l}$ of $0.2 \mathrm{M}$ sodium acetate buffer (pH 4.8), $25 \mu \mathrm{l}$ of DNA $(0.4 \mathrm{mg} / \mathrm{ml}), 10 \mu \mathrm{l}$ of $6 \times$ $10^{-5} \mathrm{M}$ potassium iodide, $12.5 \mu \mathrm{l}$ of distilled water, and $2.5 \mu \mathrm{l}$ of ${ }^{125} \mathrm{I}(40 \mu \mathrm{Ci} / \mu \mathrm{l})$ was added to a $1-\mathrm{ml}$ serum vial. The vial was capped, and a partial vacuum was formed by withdrawing $1 \mathrm{ml}$ of air with a syringe. The reaction was initiated by injecting $25 \mu \mathrm{l}$ of $\mathrm{TlCl}_{3}(1 \mathrm{mg} /$ $\mathrm{ml}$ in $50 \mathrm{mM}$ sodium acetate buffer, $\mathrm{pH} 4.8$ ). The vial was incubated in a $70^{\circ} \mathrm{C}$ water bath for $20 \mathrm{~min}$. The reaction was stopped by chilling the vial in an ice bath and then adding $0.2 \mathrm{ml}$ of $0.5 \mathrm{M}$ sodium phosphate buffer ( $\mathrm{pH}$ 6.8) containing $10 \mathrm{mM}$ mercaptoethanol. The vial was then incubated for an additional $20 \mathrm{~min}$ at $70^{\circ} \mathrm{C}$ and again cooled in an ice bath. The mixture was removed with a syringe and then passed through a Sephadex PD10 disposable column (Pharmacia Fine Chemicals, Inc., Piscataway, N.J.) by using $1 \times$ SSC $(0.15 \mathrm{M} \mathrm{NaCl}$ plus $0.015 \mathrm{M}$ sodium citrate, $\mathrm{pH}$ 7.0) as 
the elution buffer. The front peak $(2.0 \mathrm{ml})$ was collected in a tube to which $45 \mu \mathrm{g}(75 \mu \mathrm{l}$ of a $600-\mu \mathrm{g} / \mathrm{ml}$ solution) of sheared, denatured salmon sperm DNA had been added. The front peak material was heated for $20 \mathrm{~min}$ at $70^{\circ} \mathrm{C}$ and then passed through a second Sephadex PD10 column equilibrated against $0.1 \times$ SSC-1 mM HEPES ( $N$-2-hydroxyethylpiperazine- $N^{\prime}-2-$ ethanesulfonic acid) buffer (pH 7.0). The front peak was collected in a $3.5-\mathrm{ml}$ volume. The specific activities of the DNA preparations were $1 \times 10^{6}$ to $2 \times 10^{6} \mathrm{cpm} / \mu \mathrm{g}$.

DNA homology methods. DNA homology values were determined by using an S1 nuclease procedure, as described previously (17). The reassociation vials were incubated for $24 \mathrm{~h}$ at $61^{\circ} \mathrm{C}$ for reference strain VPI $2381,62^{\circ} \mathrm{C}$ for reference strain VPI $9343,64^{\circ} \mathrm{C}$ for reference strains VPI 12530 and VPI D1C-20, and $65^{\circ} \mathrm{C}$ for reference strain VPI 10043.

\section{RESULTS AND DISCUSSION}

Consistent with the original report by Oliver and Wherry (28), all strains in this study fer- mented glucose, lactose, maltose, and sucrose, and most strains produced dark pigment on hemolyzed blood agar. Of the 61 strains studied, 11 had 62 to $78 \%$ homology with the type strain of $B$. melaninogenicus subsp. melaninogenicus (VPI 2381, the parent strain of ATCC 25845), 8 had 26 to $42 \%$ homology with VPI 2381 (Table 1 ), and 41 had no or only negligible homology with VPI 2381. Of the eight strains having moderate DNA homology with VPI 2381, five of five strains tested had 66 to $82 \%$ DNA homology with reference DNA from VPI 9343 (Table 1). Of the 41 isolates which had negligible homology with VPI 2381,26 had 48 to $98 \%$ homology with reference DNA from VPI 10043 (Table 2), 7 had 61 to $86 \%$ homology with reference DNA from ATCC 15930 (VPI 0037) and 6 having moderate homology with ATCC 15930 had 67 to $73 \%$ homology with reference DNA from VPI D1C20 (Table 3).

TABLE 1. Strains in the VPI 2381 homology group (B. melaninogenicus) and their sources

\begin{tabular}{|c|c|c|c|}
\hline \multirow[t]{2}{*}{ VPI nó. } & \multicolumn{2}{|c|}{$\begin{array}{l}\text { \% DNA homology } \\
\text { with reference DNA } \\
\text { of: }\end{array}$} & \multirow[t]{2}{*}{ Strain derivation and other information ${ }^{a}$} \\
\hline & VPI 2381 & VPI 9343 & \\
\hline 2381 & $100^{b}$ & 44 & $\begin{array}{l}\text { Finegold B282, sputum; parent strain of ATCC } 25845 \text { (type strain of B. } \\
\text { melaninogenicus subsp. melaninogenicus [Approved Lists, 1980]) }\end{array}$ \\
\hline 5693 & 76 & 45 & Cystic acnes \\
\hline $7169 \mathrm{~A}$ & 71 & & Fulghum 1502a1; intestinal contents, Whipple's disease \\
\hline $7216 \mathrm{D}$ & 67 & 26 & Mouth abscess \\
\hline 7465 & 78 & 46 & Abdominal abscess \\
\hline 8227 & 69 & & Gingival crevice, periodontally healthy person \\
\hline 9847 & 76 & 45 & Gingival crevice, periodontally healthy person \\
\hline 12509 & 66 & 48 & Williams S2-77 \\
\hline 13018 & 63 & & Socransky 2 \\
\hline 13019 & 62 & & Socransky 7 (from same patient as Socransky 2) \\
\hline 13020 & 69 & & Socransky 8 (from same site as Socransky 7) \\
\hline D26C-21B & 64 & 44 & Gingival sulcus, severe periodontitis \\
\hline 9343 & 31 & $100^{b}$ & Lambe $58-71 \mathrm{~A}^{c}$ \\
\hline 7673A & 37 & 74 & Anticubical space \\
\hline 13040 & 37 & 80 & Socransky 95 \\
\hline 13041 & 33 & 66 & Socransky 96 (from same site as Socransky 95) \\
\hline D13A-25 & 42 & 82 & Tooth surface, severe periodontitis \\
\hline D45A-30 & 42 & 78 & Tooth surface, juvenile periodontitis \\
\hline 13022 & 39 & & Socransky 11 \\
\hline 6093 & 26 & & Lambe $961-70 \mathrm{C}$, colostomy wound \\
\hline
\end{tabular}

a ATCC, American Type Culture Collection, Rockville, Md.; Finegold, S. M. Finegold, Wadsworth Veterans Administration Hospital, Los Angeles, Calif.; Fulghum, R. S. Fulghum, Department of Microbiology and Immunology, School of Medicine, East Carolina University, Greenville, N.C.; Lambe, D. W. Lambe, Jr., Department of Microbiology, East Tennessee State University, Johnson City, Tenn.; Socransky, S. S. Socransky, Forsyth Dental Center, Boston, Mass.; Williams, R. A. D. Williams, The London Hospital Medical College, London, England. Unless otherwise designated, strains were isolated at the Anaerobe Laboratory, Virginia Polytechnic Institute and State University. All isolates were from humans. Tooth surface samples were taken coronal to the gingival margins of affected sites after superficial cleaning of the surfaces with sterile toothpicks. Juvenile periodontitis samples were from individuals 11 to 25 years old with severe destruction essentially limited to permanent first molars and incisors; severe periodontitis samples were from persons 18 to 30 years old with $5 \mathrm{~mm}$ or more loss of attachment on any surface of eight or more teeth not limited to first molars or incisors.

${ }^{b}$ Percent homology with reference DNA was normalized to $100 \%$.

$c$ See reference 20. 
TABLE 2. Strains in the VPI 10043 (B. denticola) homology group and their sources

\begin{tabular}{|c|c|c|}
\hline VPI no. & $\begin{array}{c}\text { \% DNA } \\
\text { homology with } \\
\text { reference DNA of } \\
\text { VPI } 10043\end{array}$ & Strain derivation and other information ${ }^{a}$ \\
\hline 10043 & $100^{b}$ & Lambe $1282-74$, maxillary antrium; parent strain of ATCC $33185^{c}$ \\
\hline $7570 \mathrm{~A}$ & 87 & Abscess of mandible \\
\hline 9955 & 86 & Lambe $1504-74 \mathrm{~A}$, pleural abscess \\
\hline 10099 & 91 & Lambe 57-75D \\
\hline 11963 & 72 & Parkland Hospital, Dallas, Tex., strain 82316, spinal fluid \\
\hline 12406 & 85 & Barnes 1221 , originally from Socransky \\
\hline 12512 & 82 & Williams S-3-77, plaque \\
\hline 13023 & 80 & Socransky 13 \\
\hline D2B-18 & 79 & Gingival sulcus, moderate periodontitis \\
\hline D2B-22 & 65 & Moderate periodontitis, same site as D2B-18 \\
\hline D2B-34A & 93 & Moderate periodontitis, same site as D2B-18 \\
\hline D16A-3 & 77 & Tooth surface, moderate periodontitis \\
\hline D19B-6B & 85 & Gingival sulcus, juvenile periodontitis \\
\hline D22A-18 & 86 & Tooth surface, juvenile periodontitis \\
\hline D25A-28 & 80 & Tooth surface, juvenile periodontitis \\
\hline D25C-2A & 84 & $\begin{array}{l}\text { Tooth surface, juvenile periodontitis, same patient as D25A-28; parent strain } \\
\text { of ATCC } 33184\end{array}$ \\
\hline D27A-11 & 50 & Tooth surface, severe periodontitis \\
\hline D27B-3 & 48 & Gingival sulcus, severe periodontitis; same patient as D27A-11 \\
\hline D27B-16 & 52 & Severe periodontitis, from same sample as D27B-3 \\
\hline D27B-25 & 83 & Severe periodontitis, from same sample as D27B-3 \\
\hline D27C-3 & 88 & Tooth surface, severe periodontitis, same patient as D27B-25 \\
\hline D28C-5 & 91 & Tooth surface, severe periodontitis \\
\hline D28C-22 & 53 & Tooth surface, severe periodontitis, from same sample as D28C-5 \\
\hline D28J-29A & 98 & Severe periodontitis, same site as D28C-5, sampled 6 weeks later \\
\hline D33B-28 & 58 & Gingival sulcus, juvenile periodontitis \\
\hline D33D-10B & 83 & Juvenile periodontitis, from same sample as D33B-28 \\
\hline E1H-6 & 86 & Gingival crevice, experimental gingivitis, no-brushing day 11 \\
\hline
\end{tabular}

a Moderate periodontitis samples were from individuals 35 . to 55 years old with chronic periodontitis generalized to all four quadrants, pocket depths of 5 to $7 \mathrm{~mm}$, and no history of rapid loss of attachment. Also see Table 1, footnote $a$.

${ }^{b}$ Percent homology with reference DNA was normalized to $100 \%$.

$c$ See reference 21 .

TABLE 3. Strains in the ATCC 15930 (VPI 0037) (B. loescheii) homology group and their sources

\begin{tabular}{|c|c|c|c|}
\hline \multirow[t]{2}{*}{ VPI no. } & \multicolumn{2}{|c|}{$\begin{array}{l}\text { \% DNA homology with } \\
\text { reference DNA of: }\end{array}$} & \multirow{2}{*}{ Strain derivation and other information ${ }^{a}$} \\
\hline & VPI 0037 & VPI D1C-20 & \\
\hline 0037 & $100^{b}$ & 41 & ATCC 15930 , Loesche $8 \mathrm{~B}$, gingival crevice \\
\hline 9621 & 82 & 41 & Lambe 221-72E, Lambe serotype $A^{c}$ \\
\hline 12530 & 76 & & Socransky 287 \\
\hline 12531 & 86 & & Socransky 379 \\
\hline D16B-5 & 61 & 42 & Gingival sulcus, moderate periodontitis \\
\hline D45C-10A & 81 & & Tooth surface, periodontally healthy person \\
\hline E1S-8 & 79 & & Gingival crevice, experimental gingivitis, no-brushing day 11 \\
\hline E1X-22A & 80 & 45 & $\begin{array}{l}\text { Gingival crevice, experimental gingivitis, no-brushing day } 26 \text {, same } \\
\text { person as E1S-8 }\end{array}$ \\
\hline D1C-20 & 38 & $100^{b}$ & Gingival sulcus, moderate periodontitis \\
\hline D18A-29A & 39 & 73 & Tooth surface, moderate periodontitis \\
\hline D25B-5 & & 70 & Gingival sulcus, juvenile periodontitis \\
\hline D26C-18 & 37 & 73 & Tooth surface, severe periodontitis \\
\hline D39D-9 & 44 & 71 & Gingival sulcus, juvenile periodontitis \\
\hline D41A-24B & 38 & 67 & Tooth surface, periodontally healthy person \\
\hline
\end{tabular}

\footnotetext{
${ }^{a}$ See Table 1 , footnote $a$.

${ }^{b}$ Percent homology with reference DNA was normalized to $100 \%$.

c See reference 20 .
} 
TABLE 4. DNA homology among some saccharoclastic Bacteroides strains

\begin{tabular}{|c|c|c|c|}
\hline \multirow[t]{2}{*}{ Strain $^{a}$} & \multicolumn{3}{|c|}{$\begin{array}{c}\text { \% Homology with } \\
\text { reference DNA from } \\
\text { strain: }{ }^{b}\end{array}$} \\
\hline & $\begin{array}{l}\text { VPI } \\
2381\end{array}$ & $\begin{array}{c}\text { VPI } \\
10043\end{array}$ & $\begin{array}{l}\text { VPI } \\
\mathbf{0 0 3 7}\end{array}$ \\
\hline $\begin{array}{l}\text { B. melaninogenicus VPI } \\
2381 \text { (ATCC 25845) }\end{array}$ & 100 & 7 & 2 \\
\hline $\begin{array}{l}\text { B. denticola VPI 10043, } \\
\text { (ATCC 33185) }\end{array}$ & 8 & 100 & 3 \\
\hline $\begin{array}{l}\text { B. loescheii ATCC } 15930 \\
\text { (VPI 0037) }\end{array}$ & 2 & 5 & 100 \\
\hline $\begin{array}{l}\text { B. melaninogenicus subsp. } \\
\text { intermedius VPI } 4197 \\
\text { (ATCC 25611) }\end{array}$ & 2 & 6 & 1 \\
\hline VPI 8944 (ATCC 33563) & 2 & 4 & 1 \\
\hline VPI 9342 (ATCC 33547) & 4 & 9 & 2 \\
\hline $\begin{array}{l}\text { B. oralis VPI D27B-24 } \\
\text { (ATCC 33269) }\end{array}$ & 3 & 3 & $\mathbf{0}$ \\
\hline
\end{tabular}

a Strains ATCC 25845, ATCC 15930, ATCC 25611, and VPI D27B-24 are type or proposed type strains.

b Percent homology with reference DNA was normalized to $100 \%$.

The homology values among VPI 2381, VPI 10043, and VPI 0037 (ATCC 15930) reference DNA preparations and DNAs from the type and reference strains of $B$. melaninogenicus subsp. intermedius and the type strain of $B$. oralis are given in Table 4.

There was negligible intragroup homology among the groups represented by strains ATCC 25845 (VPI 2381), ATCC 33185 (VPI 10043), and ATCC 15930 (VPI 0037). These strains also had negligible homology either with the type strains of species that are phenotypically similar or with other strains of saccharoclastic pigmented $\mathrm{BaC}$ teroides that have been classified as $B$. melaninogenicus subsp. intermedius. Therefore, we believe that strains ATCC 25845, ATCC 33185, and ATCC 15930 represent separate species.

Because all strains studied are anaerobic, nonmotile, nonsporeforming, gram-negative rods that produce succinate and acetate as major fermentation products, they are members of the genus Bacteroides $(12,13)$.

ATCC 25845 is the type strain of $B$. melaninogenicus. ATCC 33185 (VPI 10043) is representative of the 41 strains of $B$. denticola that we studied. The name $B$. loescheii, with ATCC 15930 as the type strain, is proposed for the third homology group.

Strains in the VPI 9343 group show only moderate homology with $B$. melaninogenicus VPI 2381 and cannot be differentiated from strains in the VPI 2381 group by usual phenotypic reactions. The relationship between the VPI 9343 and VPI 2381 homology groups (36 to 37\%) is lower than that previously observed by mem- brane competition experiments (65 to 70\%) (15) between the two homology groups within Bacteroides fragilis (VPI 2553 and VPI 2393). Even though values in the homology range of $60 \%$ or below usually are 10 to $15 \%$ lower with the $S 1$ nuclease method (used in our experiments) than with the membrane competition method (unpublished data), there is justification for considering the VPI 9343 homology group a separate species. However, until new tests reveal distinct phenotypic differences between the VPI 2381 and VPI 9343 homology subgroups or until differences in clinical or ecological significance can be established, we will consider strains in the VPI 9343 group to be members of $B$. melaninogenicus.

Similarly, strains in the VPI D1C-20 homology group show moderate (average, 39\%) intragroup homology with $B$. loescheii and are not distinguishable from $B$. loescheii by the usual phenotypic characteristics. We will consider strains with high homology with VPI D1C-20 to be members of $B$. loescheii until distinct differences in phenotypic characteristics or significance can be established.

The VPI 2381 and VPI 9343 homology subgroups are distinguishable by PAGE patterns of soluble proteins (Fig. 1), but the patterns of the strains in the ATCC 15930 and VPI D1C-20 subgroups are very similar (Fig. 1).

The phenotypic characteristics of the type or reference strains of the three species are given in Table 5 and in the descriptions below. The PAGE patterns of representative strains within the groups are given in Fig. 1 and 2.

Because there are several distinct taxa among the strains that have been classified as $B$. melaninogenicus subsp. melaninogenicus, previous research concerning the characteristics of " $B$. melaninogenicus" is difficult to interpret unless specific strains can be identified. The relationships of some reference strains to the homology groups described here and elsewhere are given in Table 6. Information from many literature citations has been included in the species descriptions given below.

Emended description of Bacteroides melaninogenicus (Oliver and Wherry 1921) Roy and Kelly 1939, 569. (Bacteroides melaninogenicus subsp. melaninogenicus (Oliver and Wherry 1921) Holdeman and Moore 1970, 33 (Approved Lists, 1980)). This species is composed of obligately anaerobic, nonsporeforming, nonmotile, gramnegative rods. Cells from glucose broth cultures were 0.5 to 0.8 by 0.9 to $2.5 \mu \mathrm{m}$, with occasional cells $10 \mu \mathrm{m}$ long or longer (Fig. 3 ).

Surface colonies on blood agar were 0.5 to 2.0 $\mathrm{mm}$ in diameter, circular, entire, convex, and shiny; they usually were darker in the center of the colony, and the edges were gray to light 


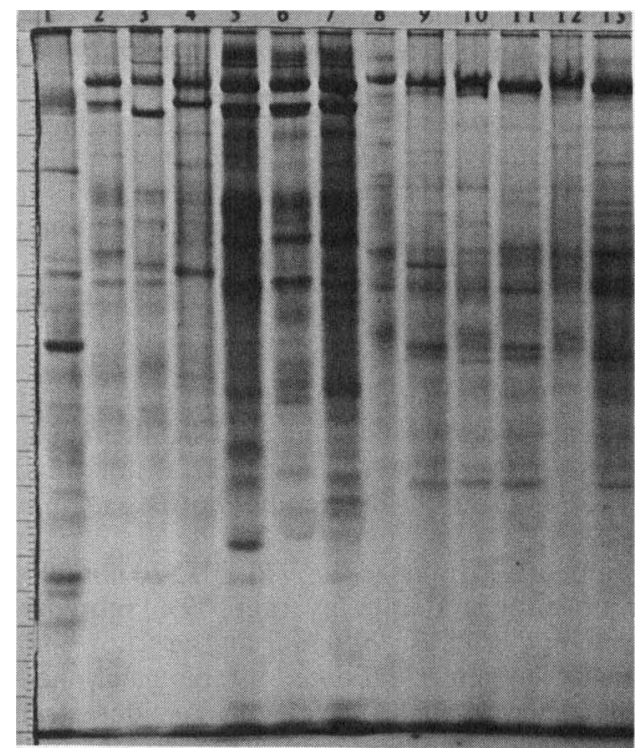

FIG. 1. PAGE patterns of strains that have high homology with $B$. melaninogenicus VPI 2381 (lane 2, VPI 5693; lane 3, VPI 7169A; lane 4, VPI 2381) and VPI 9343 (lane 5, VPI 9343; lane 6, VPI D13A-25; lane 7, VPI 13040) and with B. loescheii ATCC 15930 (lane 8, VPI 12530; lane 9, VPI D45C-10A; lane 10, ATCC 15930) and VPI D1C-20 (lane 11, VPI D1C-20; lane 12, VPI D18A-29A; lane 13, VPI D26C-18). Lane 1 contained a Streptococcus faecalis VPI U4-20 reference culture.

brown. Colonies became darker upon continued incubation ( 5 to 14 days). Dark pigment usually developed more rapidly when hemolyzed (laked) blood rather than blood containing whole erythrocytes was used. Some strains did not produce colonies with black pigment on horse blood agar but pigmented well on agar containing rabbit blood. The type strain and two other strains were beta-hemolytic on rabbit blood agar.

Glucose broth cultures usually were turbid, with smooth or stringy sediment and a pH of 4.6 to 5.0 .

The major fermentation acids (from $1 \%$ peptone-1\% yeast extract-1\% glucose broth cultures containing vitamin $K_{1}$ and hemin [11]) of the type strain were succinate $(2 \mathrm{meq} / 100 \mathrm{ml}$ of culture) and acetate $(2 \mathrm{meq} / 100 \mathrm{ml})$; sometimes formate $(0.5$ to $1.0 \mathrm{meq} / 100 \mathrm{ml})$ was also present. Small amounts (less than $0.3 \mathrm{meq} / 100 \mathrm{ml}$ ) of isobutyrate and isovalerate usually were detected in medium containing 1 to $2 \%$ peptone. No hydrogen was detected in headspace gas. Similar products were obtained with other strains. Neither lactate nor pyruvate was utilized. Threonine was not converted to propionate.

Hemin $(1 \mu \mathrm{g} / \mathrm{ml})$ was required for growth of the type strain. Hemin or vitamin $K_{1}(0.1 \mu \mathrm{g} / \mathrm{ml})$ or both were required for or enhanced growth of most strains. Most strains grew at pH 8.5 and $25^{\circ} \mathrm{C}$; some grew at $45^{\circ} \mathrm{C}$.

Cell wall peptidoglycan may contain either lysine or diaminopimelic acid. No heptose or 2keto-3-deoxyoctulosonic acid is detected (9). Cells contain sphingolipids (25) and have superoxide dismutase activity (8).

The type strain reacts with Lambe group A fluorescent antibody conjugate (20).

Other characteristics of the species are given in Table 5.

Strains have been isolated from human gingival crevices and from human clinical specimens.

The guanine-plus-cytosine content of the DNA is 36 to $40 \mathrm{~mol} \%$ (37, 41; this study).

Type strain: ATCC 25845 (VPI 2381, Finegold B282).

Emended description of Bacteroides denticola Shah and Collins 1981, 237. This species is composed of obligately anaerobic, nonmotile, nonsporeforming, gram-negative rods. Cells from glucose broth cultures were 0.5 to 0.7 by 0.7 to $6.0 \mu \mathrm{m}$ and usually occurred in pairs and short chains (Fig. 4).

Surface colonies on blood agar were 1 to $2 \mathrm{~mm}$ in diameter, circular, entire, low convex, semiopaque, shiny, and smooth, often appearing to have white or buff concentric rings. Pigmented colonies developed more rapidly and to a darker color on rabbit blood agar than on sheep blood agar. Most strains produced dark brown or black colonies within 7 days on medium containing hemolyzed rabbit blood; 2 of 20 strains never developed colonies with definite pigment.

Glucose broth cultures were turbid, with a smooth sediment and a pH of 4.2 to 4.8 .

The major fermentation acids (from $1 \%$ peptone- $1 \%$ yeast extract-1\% glucose broth cultures containing vitamin $K_{1}$ and hemin [11]) of strain VPI 10043 (ATCC 33185) were succinate ( $2 \mathrm{meq} / 100 \mathrm{ml}$ of culture) and acetate $(2 \mathrm{meq} / 100$ $\mathrm{ml})$; sometimes lactate $(0.2$ to $0.3 \mathrm{meq} / 100 \mathrm{ml})$ was also present. Small amounts (less than $\mathbf{0 . 3}$ $\mathrm{meq} / 100 \mathrm{ml}$ of culture) of isobutyrate and isovalerate often were detected in medium containing 1 to $2 \%$ peptone. No hydrogen was detected in headspace gas. Similar products were obtained with other strains.

Hemin was required or highly stimulatory for growth of ATCC 33185 and the other strains; vitamin $K_{1}$ generally was not required.

Of 19 strains tested, 15 were susceptible to chloramphenicol $(12 \mu \mathrm{g} / \mathrm{ml})$, clindamycin $(1.6$ $\mu \mathrm{g} / \mathrm{ml})$, penicillin $\mathrm{G}(2 \mathrm{U} / \mathrm{ml})$, and tetracycline $(6$ $\mu \mathrm{g} / \mathrm{ml})$. ATCC 33185 and four other strains were resistant to $2 \mathrm{U}$ of penicillin $\mathrm{G}$ per $\mathrm{ml}$, and one of these strains also was resistant to $6 \mu \mathrm{g}$ of tetracycline per $\mathrm{ml}$.

No heptose or 2-keto-3-deoxyoctulosonic acid 


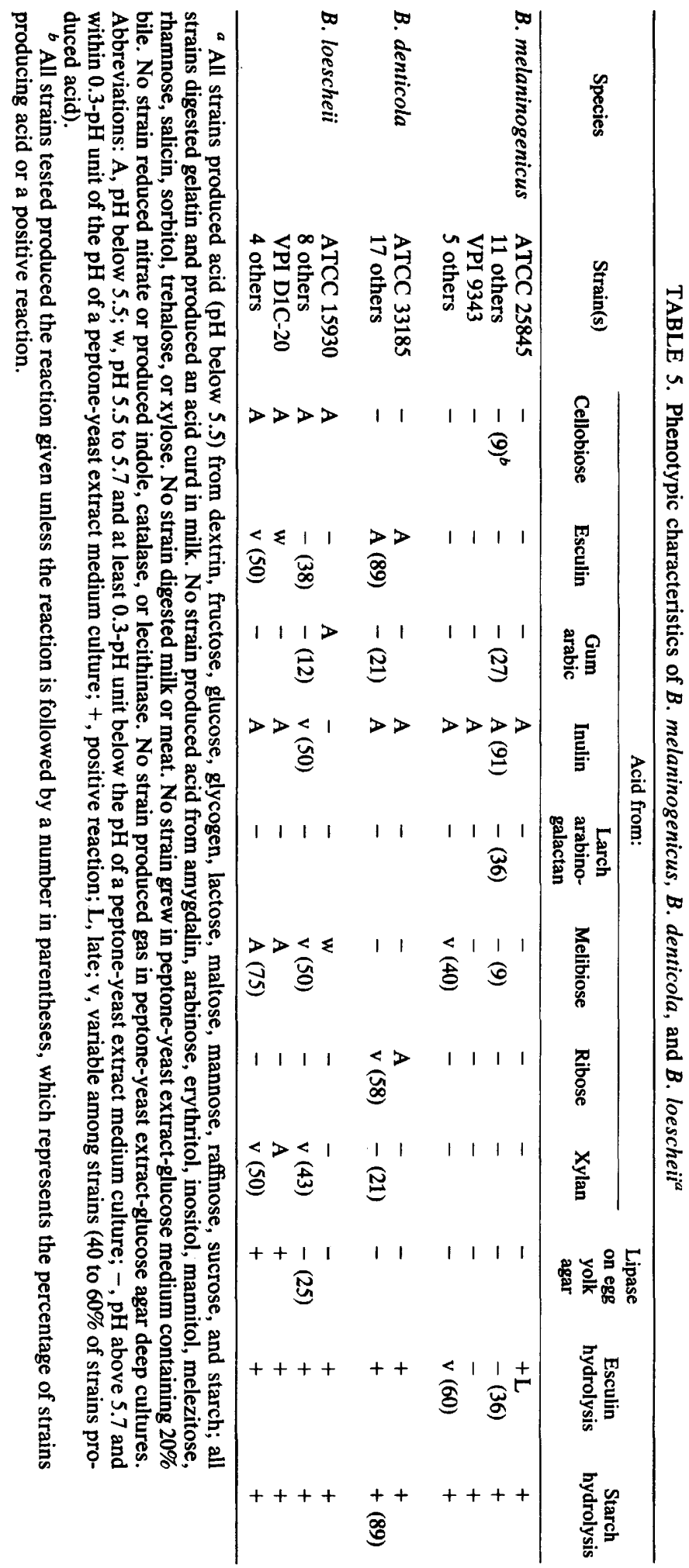




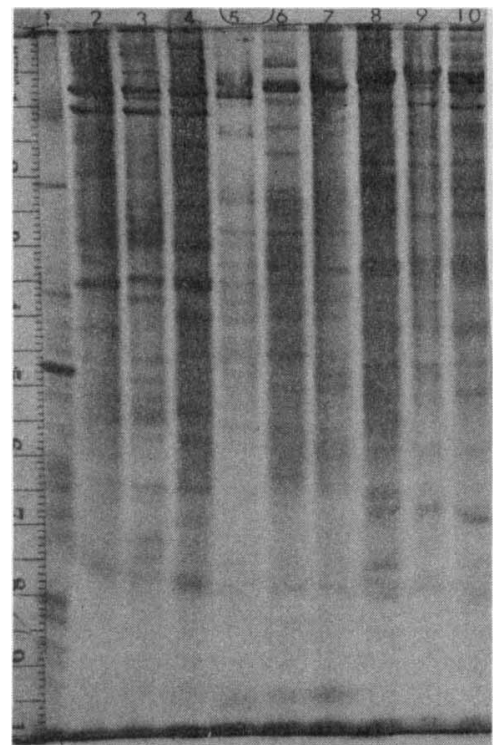

FIG. 2. PAGE patterns of strains of $B$. melaninogenicus, $B$. loescheii, and $B$. denticola. Lane $1, S$. faecalis VPI U4-20 reference culture; lanes 2 to $4, B$. melaninogenicus (lane 2, VPI 2381 [ATCC 25845, type strain]; lane 3, VPI 9847; lane 4, VPI 13020); lanes 5 to 7, B. loescheii (lane 5, ATCC 15930; lane 6, VPI 12530; lane 7, VPI 9621); lanes 8 to $10 \mathrm{~B}$. denticola (lane 8, VPI 10043 [ATCC 33185]; lane 9, VPI 9955; lane 10, VPI 13023).

is detected (in the strain referred to as " $B$. oralis VPI 7570A") (9).

Other characteristics of the species are given in Table 5 and by Shah and Collins (36).
Tests for hydrolysis of esculin and fermentation of cellobiose are helpful in differentiating $B$. denticola from $B$. melaninogenicus and $B$. loescheii.

Strains have been isolated from human gingival crevices and human clinical specimens.

The guanine-plus-cytosine content of the DNA is 49 to $51 \mathrm{~mol} \%$ in this study. Shah and Collins reported $51 \mathrm{~mol} \%$ for the two strains that they studied (36).

Type strain: NCDO 2352 (Shah and Collins 1210).

Bacteroides loescheii Holdeman and Johnson sp. nov. (loesche'i.i. L. gen. noun loescheii of Loesche, named after Walter J. Loesche, an American dental microbiologist). This species is composed of obligately anaerobic, nonsporeforming, nonmotile, gram-negative rods. Cells in glucose broth were 0.4 to 0.6 by 0.8 to $15.0 \mu \mathrm{m}$ and occurred singly, in pairs, and in short chains (Fig. 5).

Surface colonies on anaerobic blood agar plates were 1 to $2 \mathrm{~mm}$ in diameter, circular, entire, low convex, translucent, shiny, and smooth. After incubation for $48 \mathrm{~h}$ on plates containing whole blood, colonies were white or buff. Upon continued anaerobic incubation (up to 14 days), colonies usually became brown (often only light brown). Although pigment developed more rapidly on media containing hemolyzed blood, definite dark brown or black colonies did not develop with some strains, even if cultures were incubated for 21 days. The pigment is formed principally from protoporphyrin (35). Most strains produced slight clearing or beta-hemolysis on rabbit blood agar.

TABLE 6. Proposed classification of some commonly used reference strains of pigmenting Bacteroides previously classified as $B$. melaninogenicus subsp. melaninogenicus or $B$. oralis

\begin{tabular}{|c|c|c|c|}
\hline \multirow{2}{*}{ Published strain no. ${ }^{a}$} & \multicolumn{2}{|c|}{ Identification or classification } & \multirow{2}{*}{ Reference(s) } \\
\hline & Present & Previous & \\
\hline $\begin{array}{l}\text { ATCC } 25845 \text { (VPI 2381, } \\
\text { WAL B282) }\end{array}$ & B. melaninogenicus & $\begin{array}{l}\text { B. melaninogenicus subsp. } \\
\text { melaninogenicus }\end{array}$ & $7,16,22,27,40,41$ \\
\hline $\begin{array}{l}\text { Lambe 138-71, serogroup } \\
\text { A (VPI 9847) }\end{array}$ & B. melaninogenicus & $\begin{array}{l}\text { B. melaninogenicus subsp. } \\
\text { melaninogenicus }\end{array}$ & 20,37 \\
\hline VPI 9343 (Lambe 58-71A) & B. melaninogenicus & $\begin{array}{l}\text { B. melaninogenicus subsp. } \\
\text { melaninogenicus }\end{array}$ & 40,41 \\
\hline $\begin{array}{l}\text { ATCC } 33185 \text { (VPI 10043, } \\
\text { DWL 1282-74B) }\end{array}$ & B. denticola & $\begin{array}{l}\text { B. melaninogenicus subsp. } \\
\text { melaninogenicus }\end{array}$ & 16 \\
\hline VPI $7570 \mathrm{~A}$ & B. denticola & $\begin{array}{l}\text { B. melaninogenicus subsp. } \\
\text { melaninogenicus, } B . \\
\text { oralis }\end{array}$ & 9,10 \\
\hline $\begin{array}{l}\text { Socransky } 287 \text { (VPI } \\
\text { 12530) }\end{array}$ & B. denticola & B. melaninogenicus & 16 \\
\hline $\begin{array}{l}\text { ATCC } 15930 \text { (VPI } 9085 \text {, } \\
\text { Loesche 8B) }\end{array}$ & B. loescheii & $\begin{array}{l}\text { B. melaninogenicus subsp. } \\
\text { melaninogenicus, } B . \\
\text { oralis }\end{array}$ & $\begin{array}{l}9,22,27,35,37,40,43 \\
45\end{array}$ \\
\hline Socransky 379 & B. loescheii & $\begin{array}{l}\text { B. melaninogenicus subsp. } \\
\text { melaninogenicus }\end{array}$ & 22 \\
\hline
\end{tabular}

a See Table 1, footnote a. Strains ATCC 25845 and ATCC 15930 are type strains. 


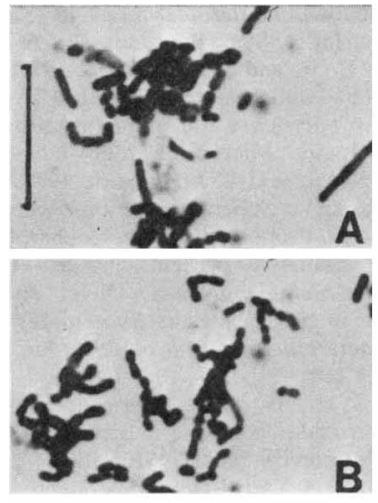

FIG. 3. Gram stains of 24-h broth cultures of $B$. melaninogenicus VPI 2381 (ATCC 25845) in peptoneyeast extract medium (A) and peptone-yeast extractglucose medium (11) (B). Bar $=1 \mu \mathrm{m}$.

Glucose broth cultures were turbid, with a smooth sediment and a final pH of 4.9 to 5.4.

The major fermentation acids (from $1 \%$ peptone-1\% yeast extract-1\% glucose broth cultures containing vitamin $K_{1}$ and hemin [11]) of the type strain were succinate ( 2 to $3 \mathrm{meq} / 100 \mathrm{ml}$ of culture) and acetate $(1 \mathrm{meq} / 100 \mathrm{ml})$; sometimes traces of lactate $(0.2$ to $0.3 \mathrm{meq} / 100 \mathrm{ml})$ and formate $(0.2$ to $0.3 \mathrm{meq} / 100 \mathrm{ml})$ were also present. No hydrogen was detected in headspace gas. Similar products were obtained with other strains. Neither pyruvate nor lactate was used, and threonine was not converted to propionate.

Hemin was required or highly stimulatory for growth. Even in the presence of hemin, serum $(10 \%, \mathrm{vol} / \mathrm{vol})$ often enhanced growth and fermentation.

The six strains tested were susceptible to

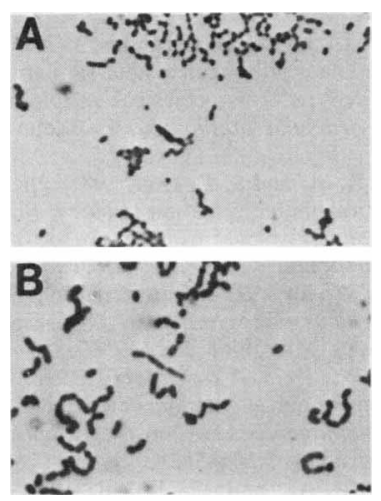

FIG. 4. Gram stains of 24-h broth cultures of $B$. denticola VPI 10043 (ATCC 33185) in peptone-yeast extract medium (A) and peptone-yeast extract-glucose medium (11) (B). Same magnification as in Fig. 3.

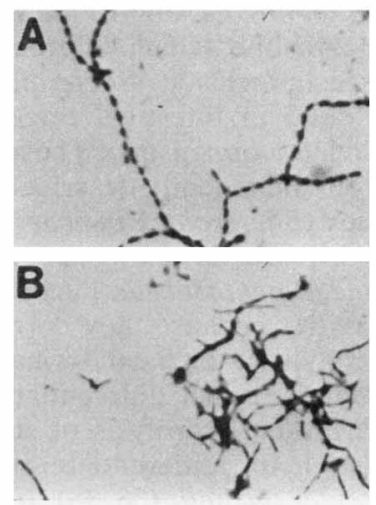

FIG. 5. Gram stains of 24-h broth cultures of $B$. loescheii ATCC 15930 in peptone-yeast extract medium (A) and peptone-yeast extract-glucose medium (11) (B). Same magnification as in Fig. 3.

chloramphenicol $(12 \mu \mathrm{g} / \mathrm{ml})$, clindamycin $(1.6$ $\mu \mathrm{g} / \mathrm{ml})$, penicillin $\mathrm{G}(2 \mathrm{U} / \mathrm{ml})$, and tetracycline $(6$ $\mu \mathrm{g} / \mathrm{ml})$.

The type strain (referred to as " $B$. oralis ATCC 15930") produces sphingolipids (25). Extracellular phospholipase A is produced (3).

Other characteristics of the species are given in Table 5.

Hydrolysis of esculin and fermentation of cellobiose are helpful in differentiating $B$. loescheii from $B$. melaninogenicus and $B$. denticola.

Isolated from gingival crevices of humans.

The guanine-plus-cytosine content of the DNA is $46 \mathrm{~mol} \%$ (37) or 47 to $48 \mathrm{~mol} \%$ (41; this study).

Type strain: ATCC 15930 (Loesche strain 8B, NCTC 11321).

Additional comments. Loesche strain 8B originally was deposited with the American Type Culture Collection as a representative of $B$. oralis. Concurrent with the interest in Bacteroides in the last two decades and with improved methods for culture of the organisms, many investigators independently observed that ATCC 15930 produced colonies with brown or black pigment on blood agar, particularly if the blood was hemolyzed $(10,37)$. Because pigment was observed in this saccharoclastic organism, ATCC 15930 was reidentified by W. E. C. Moore and one of us (L.V.H.) as a strain of $B$. melaninogenicus subsp. melaninogenicus, and it was so listed in the 14th edition of the catalog of the American Type Culture Collection (1). This strain has been referred to as both $B$. oralis and $B$. melaninogenicus in the literature, but it is distinctly different from the type strain of $B$. oralis (Table 4).

Phenotypic characteristics helpful in differentiating $B$. melaninogenicus, $B$. denticola, and $B$. loescheii from other species. Strains of $B$. melani- 
nogenicus, $B$. denticola, and $B$. loescheii do not grow well in $20 \%$ bile, which differentiates them from the saccharoclastic Bacteroides strains commonly found in intestinal tracts (e.g., $B$. fragilis and related organisms). These three species differ from the recently described saccharoclastic species (Bacteroides buccae and Bacteroides oris [14], Bacteroides capillus [19, 38], and Bacteroides pentosaceus [36, 38]) isolated from oral cavities because they do not ferment arabinose or xylose. Pigment formation is the major characteristic that differentiates $B$. loescheii and $B$. oralis; hydrolysis of starch by $B$. loescheii also helps differentiate this species from Bacteroides buccalis $(36,38)$. B. melaninogenicus, $B$. loescheii, and $B$. denticola ferment lactose, unlike $B$. melaninogenicus subsp. intermedius; in addition, these three species ferment maltose, unlike strains of $B$. macacae and " $B$. melaninogenicus subsp. levii," and they do not produce butyric acid, as strains of $B$. asaccharolyticus and $B$. gingivalis do.

\section{ACKNOWLEDGMENTS}

We gratefully acknowledge the persons who sent the strains used in this study and the help of K. Palcanis, R. R. Ranney, and J. A. Burmeister, School of Dentistry, Virginia Commonwealth University, who selected the subjects and sites to be sampled for the periodontal samples and who obtained the samples from which we isolated strains. We thank E. P. Cato, Roger W. Kelley, and W. E. C. Moore for critical review of the manuscript. We appreciate the help of E. P. Cato and D. E. Hash in preparing the PAGE gels and the help of W. E. C. Moore for assistance in isolation and identification of the periodontal strains. We gratefully acknowledge the technical assistance of Luba S. Fabrycky, Sue C. Smith, Pamela Churn, and Ruth McCoy.

This work was supported by Public Health Service grants DE-05218, DE-05139 (Virginia Commonwealth University Clinical Research Center for Periodontal Diseases), and DE05054 from the National Institute of Dental Research, by Public Health Service grant AI-15244 from the National Institute of Allergy and Infectious Diseases, and by project 2022820 from the Commonwealth of Virginia.

\section{REPRINT REOUESTS}

Address reprint requests to: Dr. Lillian V. Holdeman, Department of Anaerobic Microbiology, College of Agriculture and Life Sciences, Virginia Polytechnic Institute and State University, Blacksburg, VA 24061.

\section{LTTERATURE CITED}

1. American Type Culture Collection. 1980. Catalogue of strains 1, 14th ed. American Type Culture Collection, Rockville, Md.

2. Bergey, D. H. 1930. Bergey's manual of determinative bacteriology, 3rd ed. The Williams \& Wilkins Co., Baltimore.

3. Bulkaca, J., M. G. Newman, S. S. Socransky, E. Newbrun, and D. F. Scott. 1979. Phospholipase A activity of microorganisms from dental plaque. Microbios Lett. 10:79-88.

4. Burdon, K. L. 1928. Bacterium melaninogenicum from normal and pathologic tissues. J. Infect. Dis. 42:161-171.

5. Coykendall, A. L., F. S. Kaczmarek, and J. Slots. 1980. Genetic heterogeneity in Bacteroides asaccharolyticus (Holdeman and Moore 1970) Finegold and Barnes 1977 (Approved Lists, 1980) and proposal of Bacteroides gingi- valis sp. nov. and Bacteroides macacae (Slots and Genco) comb. nov. Int. J. Syst. Bacteriol. 30:559-564.

6. Cummins, C. S., and J. L. Johnson. 1971. Taxonomy of the clostridia: wall composition and DNA homologies in Clostridium butyricum and other butyric acid-producing clostridia. J. Gen. Microbiol. 67:33-46.

7. Finegold, S. M., and E. M. Barnes. 1977. Report of the ICSB Taxonomic Subcommittee on Gram-Negative Anaerobic Rods. Proposal that the saccharolytic and asaccharolytic strains at present classified in the species Bacteroides melaninogenicus (Oliver and Wherry) be reclassified in two species as Bacteroides melaninogenicus and Bacteroides asaccharolyticus. Int. J. Syst. Bacteriol. 27:388-391.

8. Gregory, E. M., W. E. C. Moore, and L. V. Holdeman. 1978. Superoxide dismutase in anaerobes: survey. Appl. Environ. Microbiol. 35:988-991.

9. Hofstad, T. 1974. The distribution of heptose and 2-keto-3deoxy-octonate in Bacteroidaceae. J. Gen. Microbiol. 85:314-320.

10. Holbrook, W. P., B. I. Duerdan, and A. G. Deacon. 1977. The classification of Bacteroides melaninogenicus and related species. J. Appl. Bacteriol. 42:259-273.

11. Holdeman, L. V., E. P. Cato, and W. E. C. Moore (ed.). 1977. Anaerobe laboratory manual, 4th ed. Anaerobe Laboratory, Virginia Polytechnic Institute and State University, Blacksburg.

12. Holdeman, L. V., and W. E. C. Moore. 1974. Family I. Bacteroidaceae Pribram 1933, 10, p. 384. In R. E. Buchanan and N. E. Gibbons (ed.), Bergey's manual of determinative bacteriology, 8th ed. The Williams \& Wilkins Co., Baltimore.

13. Holdeman, L. V., and W. E. C. Moore. 1974. Genus I. Bacteroides Castellani and Chalmers 1919, 959, p. 385404. In R. E. Buchanan and N. E. Gibbons (ed.), Bergey's manual of determinative bacteriology, 8th ed. The Williams \& Wilkins Co., Baltimore.

14. Holdeman, L. V., W. E. C. Moore, P. J. Churn, and J. L. Johnson. 1982. Bacteroides oris and Bacteroides buccae, new species from human periodontitis and other human infections. Int. J. Syst. Bacteriol. 32:125-131.

15. Johnson, J. L. 1978. Taxonomy of the bacteroides. I. Deoxyribonucleic acid homologies among Bacteroides fragilis and other saccharolytic Bacteroides species. Int. J. Syst. Bacteriol. 28:245-256.

16. Johnson, J. L. 1980. Classification of anaerobic bacteria, p. 19-29. In Proceedings of International Symposium on Anaerobes, Tokyo, Japan, 22 June 1980. Nippon MerckBanyu Co., Ltd., Tokyo.

17. Johnson, J. L. 1981. Genetic characterization, p. 450-472. In P. Gerhardt (ed.), Manual of methods for general microbiology. American Society for Microbiology, Washington, D.C.

18. Johnson, J. L., and C. S. Cummins. 1972. Cell wall composition and deoxyribonucleic acid similarities among the anaerobic coryneforms, classical propionibacteria, and strains of Arachnia propionica. J. Bacteriol. 109:1047 1066.

19. Kornman, K. S., and S. C. Holt. 1981. Physiological and ultrastructural characterization of a new Bacteroides species (B. capillus) isolated from severe localized periodontitis. J. Periodontal Res. 16:542-555.

20. Lambe, D. W., Jr. 1974. Determination of Bacteroides melaninogenicus serogroups by fluorescent antibody staining. Appl. Microbiol. 28:561-567.

21. Lambe, D. W., Jr., and R. C. Jerris. 1976. Description of a polyvalent conjugate and a new serogroup of Bacteroides melaninogenicus by fluorescent antibody staining. J. Clin. Microbiol. 3:506-512.

22. Listgarten, M. A., and C.-H. Lai. 1979. Comparative ultrastructure of Bacteroides melaninogenicus subspecies. J. Periodontal Res. 14:332-340.

23. Marmur, J. 1961. A procedure for the isolation of deoxyribonucleic acid from microorganisms. J. Mol. Biol. 3:208218. 
24. Marmur, J., and P. Doty. 1962. Determination of the base composition of deoxyribonucleic acid from its thermal denaturation temperature. J. Mol. Biol. 5:109-118.

25. Mlyagawa, E., R. Azuma, and T. Suto. 1978. Distribution of sphingolipids in Bacteroides species. J. Gen. Microbiol. 24:341-348.

26. Moore, W. E. C., D. E. Hash, L. V. Holdeman, and E. P. Cato. 1980. Polyacrylamide slab gel electrophoresis of soluble proteins for studies of bacterial floras. Appl. Environ. Microbiol. 39:900-907.

27. Monton, C., P. Hammond, J. Slots, and R. Genco. 1980. Evaluation of Fluorotec-M for detection of oral strains of Bacteroides asaccharolyticus and Bacteroides melaninogenicus. J. Clin. Microbiol. 11:682-686.

28. Otiver, W. W., and W. B. Wherry. 1921. Notes on some bacterial parasites of the human mucous membranes. J. Infect. Dis. 28:341-344.

29. Prtvot, A. R. 1938. Études de systématique bactérienne. Ann. Inst. Pasteur (Paris) 60:285-307.

30. Prérot, A. R. 1957. Manual de classification et de détermination des bactéries anaerobios. Masson, Paris.

31. Roy, T. E., and C. D. Kelly. 1939. Genus Bacteroides Castellaní and Chalmers, p. 556-558. In D. H. Bergey, R. S. Breed, E. G. D. Murray, and A. P. Hitchens (ed.), Bergey's manual of determinative bacteriology, 5th ed. The Williams \& Wilkins Co., Baltimore.

32. Solyers, A. A., J. R. Vercelloti, S. E. H. West, and T. D. Wilkins. 1977. Fermentation of mucin and plant polysaccharides by strains of Bacteroides from the human colon. Appl. Environ. Microbiol. 33:319-322.

33. Sawyer, A. A., J. B. Macdonald, and R. J. Gibbons. 1962. Biochemical characteristics of Bacteroides melaninogenicus. A study of thirty-one strains. Arch. Oral Biol. 7:685691.

34. Schwabacher, H., D. R. Lucas, and C. Rimington. 1947. Bacterium melaninogenicum, a misnomer. J. Gen. Microbiol. 1:109-120.

35. Shah, H. N., R. Bonnett, B. Mateen, and R. A. D. Williams. 1979. The porphyrin pigmentation of subspecies of Bacteroides melaninogenicus. Biochem. J. 180:45-50.
36. Shah, H. N., and M. D. Collins. 1981. Bacteroides buccalis, sp. nov., Bacteroides denticola, sp. nov., and Bacteroides pentosaceus, sp. nov., new species of the genus Bacteroides from the oral cavity. Zentralbl. Bakteriol. Parasitenkd. Infektionskr. Hyg. Abt. 1 Orig. Reihe C 2:235-241.

37. Shah, H. N., R. A. D. Williams, G. H. Bowden, and J. M. Hardie. 1976. Comparison of the biochemical properties of Bacteroides melaninogenicus from human dental plaque and other sites. J. Appl. Microbiol. 41:473-492.

38. Skerman, V. D. B., V. McGowan, and P. H. A. Sneath. 1982. Validation of the publication of new names and new combinations previously effectively published outside the IJSB. List no. 8. Int. J. Syst. Bacteriol. 32:266-268

39. Tereba, A., and B. J. McCarthy. 1973. Hybridization of ${ }^{125}$ I-labelled ribonucleic acid. Biochemistry 12:4675-4679.

40. Van Steenbergen, T. J. M. 1981. Classification and virulence of black-pigmented Bacteroides strains. Vrije University, Amsterdam.

41. Van Steenbergen, T. J. M., J. J. De Soet, and J. De Graaff. 1979. DNA base composition of various strains of Bacteroides melaninogenicus. FEMS Microbiol. Lett. 5:127-130.

42. Wilkins, T. D., and T. Thlel. 1973. A modified broth-disk method for testing the antibiotic susceptibility of anaerobic bacteria. Antimicrob. Agents Chemother. 3:350-356.

43. Williams, R. A. D., G. H. Bowden, J. M. Hardie, and H. Shah. 1975. Biochemical properties of Bacteroides melaninogenicus subspecies. Int. J. Syst. Bacteriol. 25:298300 .

44. Wilson, G. S., and A. A. Miles. 1964. Topley and Wilson's principles of bacteriology and immunity. The Williams \& Wilkins Co., Baltimore.

45. Woo, D. D. L., S. C. Holt, and E. R. Leadbetter. 1979. Ultrastructure of Bacteroides species: Bacteroides asaccharolyticus, Bacteroides fragilis, Bacteroides melaninogenicus subspecies melaninogenicus, and $B$. melaninogenicus subspecies intermedius. J. Infect. Dis. 139:534546. 